\title{
METODE EXTREME PROGRAMMING PADA APLIKASI PENDATAAN WARGA BERBASIS ANDROID MENGUNAKAN APP INVENTOR (STUDI KASUS: BTN GRIYA AMBAN PANTAI KABUPATEN MANOKWARI)
}

\author{
Kristia Yuliawan \\ Jurusan Teknik Informatika \\ Fakultas Teknik Universitas Papua \\ Jalan Gunung Salju, Amban, Manokwari Barat, Amban, \\ Manokwari, Kabupaten Manokwari, Papua Barat. 98314 \\ E-mail: k.yuliawan@unipa.ac.id
}

\begin{abstract}
BTN Griya Amban Pantai consists of 54 families who are in the Amban district, Manokwari Regency. In carrying out data collection and recording of residents 'data, the household administrators are still doing it manually, where the household administrators carry out data collection by recording resident data using a form filled out by residents by visiting residents' homes. After the form is filled in, data recording is carried out using a notebook. The problem in carrying out the manual process of data collection and data recording of residents is that when officers come to the residents' houses, often the head of the family or family members is not at home so that the the householdmanagement cannot carry out data collection and data recording. To solve this problem, an Android-based data collection and data recording application is needed using the App Inventor application. The method used in making community data collection and data recording applications uses the extreme programming method where this method can develop applications that are more efficient, flexible, low risk and quick to solve. With this android application, it can simplify the performance of the management of the BTN Griya Amban the household in carrying out data collection and data recording without the need to visit residents' homes to collect and record data. The method used in testing this application is to use the blackbox method where testing is carried out focusing on the functional specifications of the software that has been made.
\end{abstract}

Keywords: Android, App Inventor, BTN Griya Amban, Extreme programming.

\section{PENDAHULUAN}

Aplikasi android adalah aplikasi yang dibangun untuk perangkat yang bergerak. Aplikasi ini dibangun dengan mengunakan bahasa pemrograman yang khusus untuk aplikasi android. Keunggulan dari aplikasi android ini adalah aplikasi ini sangat mudah untuk digunakan dan memiliki tampilan yang menarik dimana aplikasi ini bisa digunakan dengan mengunakan perangkat elektronik handphone. 
Rumah subsidi adalah program pemerintah yang dijalankan oleh Kementrian Pekerjaan Umum dan Perumahan Rakyat yang bekerja sama dengan Bank BTN yang ditujukan kepada masyarakat berpenghasilan rendah dengan cicilan ringan dengan suku bunga rendah yang telah memiliki tabungan di Bank BTN.

Proses pendataan warga di perumahan BTN Griya Amban Pantai Kabupaten manokwari dilakukan oleh pengurus RT dengan mendatangi penghuni perumahan dari pintu ke pintu dengan mengisi formulir yang telah disiapkan, kemudian dari data formulir yang telah diisi kemudian dicatat di buku catatan untuk direkap. Kegiatan pendataan secara manual ini sering menghadapi kendala yaitu pada saat petugas RT datang ke rumah sedangkan penghuni tidak berada di rumah sehingga pendataan warga tidak dapat dilaksanakan.

Untuk mengatasi permasalah tersebut maka perlu dibangun sebuah Aplikasi Pendataan dan Perakapan Data berbasis android sehingga memudahkan pengurus RT dalam melaksanakan pendataan dan perekapan data warga.

\section{METODE PENELITIAN}

\section{A. Metode Pengumpulan Data}

Metode pengumpulan data dilaksanakan dengan beberapa tahapan sebagai berikut :

1. Wawancara

Dilaksanakan dengan mewancarai ketua RT dan beberapa warga yang bertempat tinggi di BTN Griya Amban Pantai Kabupaten Nabire dengan beberapa pertanyaan yang yang berhubungan dengan pendataan warga dan kendala yang dihadapi.

2. Studi Pustaka

Pengumpulan data yang dilakukan adalah dengan cara mengumpulkan materi, data, referensi dan informasi yang relevan dengan aplikasi pendataan warga yang berasal dari internet, buku, artikel ilmiah maupun lainnya. 


\section{Studi Lapangan}

Studi lapangan dilaksanakan dengan mengambil data warga, kemudian mengolah dan menganalisanya mendapatkan laporan akhir dengan aplikasi yang telah dibuat.

\section{B. Metode Pengembangan Sistem}

Metode pengembangan sistem yang digunakan adalah metode Extreme Programming. Metode ini adalah metode pengembangan sistem yang efesien, fleksibel, beresiko rendah dan cepat. Model yang digunakan mengunakan object Oriented. Tahapan-tahapan yang digunakan dalam metode Extreme Programming adalah sebagai berikut :

1. Perencanaan (Planning).

Tahapan ini merupakan langkah awal dalam pembangunan sistem dimana dalam tahapan ini dilakukan beberapa kegiatan perencanaan yaitu, identifikasi permasalahan, menganalisa kebutuhan sampai dengan penetapan jadwal pelaksanaan pembangunan sistem.

2. Perancangan (Design).

Tahapan berikutnya adalah perancangan dimana pada tahapan ini dilakukan kegiatan pemodelan yang dimulai dari pemodelan sistem, pemodelan arsitektur sampai dengan pemodelan basis data.

3. Pengkodean (Coding)

Tahapan ini merupakan kegiatan penerapan pemodelan yang sudah dibuat kedalam bentuk user inteface dengan menggunakan bahasa pemrograman.

4. Pengujian (Testing)

Setelah tahapan pengkodean selesai, kemudian dilakukan tahapan pengujian sistem untuk mengetahui kesalahan apa saja yang timbul saat aplikasi sedang berjalan serta mengetahui apakah sistem yang dibangun sudah sesuai dengan kebutuhan pengguna. 


\section{HASIL DAN PEMBAHASAN}

\section{Perencanaan (Planning).}

A. Identifikasi Masalah

Identifikasi masalah yang akan dibuatkan ke dalam sistem aplikasi membutuhkan identifikasi semua permasalahan yang muncul pada saat perancangan sistem. Untuk menghindari hal tersebut dibutuhkan gambaran yang jelas terhadap sistem yang berjalan dalam pendataan warga griya amban pantai. Analisa tersebut dapat terlihat sebagai berikut

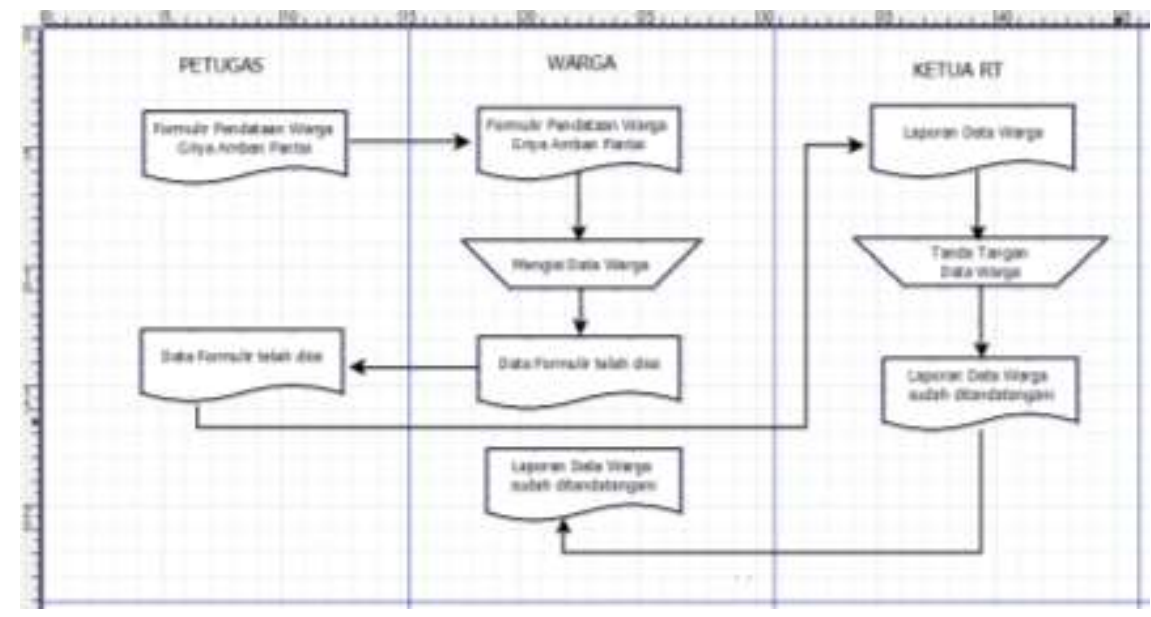

Gambar 1 : Flowachart Sistem Berjalan

B. Kebutuhan Sistem

1. Kebutuhan perangkat keras yang digunakan dalam membangun sistem adalah sebagai berikut :

Laptop yang digunakan memiliki spesifikasi sebagai berikut :

a. Processor : AMD A10-9620P RADEON R5 COMPUTE CORES 4C+6G $2.50 \mathrm{GHz}$.

b. Memory RAM : $8.00 \mathrm{~GB}$

c. System Type : 64-bit Operating System

d. Sistem Operasi : Ms. Windows 10

e. Harddisk : $4 \mathrm{~GB}$

Sedangkan Smartphone yang digunakan adalah Smartphone OPPO A1k dengan spesifikasi:

a. Layar : $6.1 \mathrm{inch}$. 
b. Resolusi layar : 720 x 1560 pixels, 19.5:9 ratio ( 282 ppi density)

c. Chipset : Mediatek MT6762 Helio P22 (12 nm)

d. OS : Android 9.0 (Pie); ColorOS 6.

e. CPU : Octa-core $2.0 \mathrm{GHz}$ Cortex-A53.

f. GPU : PowerVR GE8320.

g. RAM : 2GB.

h. Memori Internal : 32GB.

2. Kebutuhan perangkat lunak yang digunakan dalam membangun sistem adalah sebagai berikut :

a. Sistem Operasi Windows 7 Ultimate 32 bit

b. MIT App Inventor Online 2.47

c. Database Firebase

d. Mozilla Firefox

\section{Perancangan (Design).}

A. Use Case Diagram

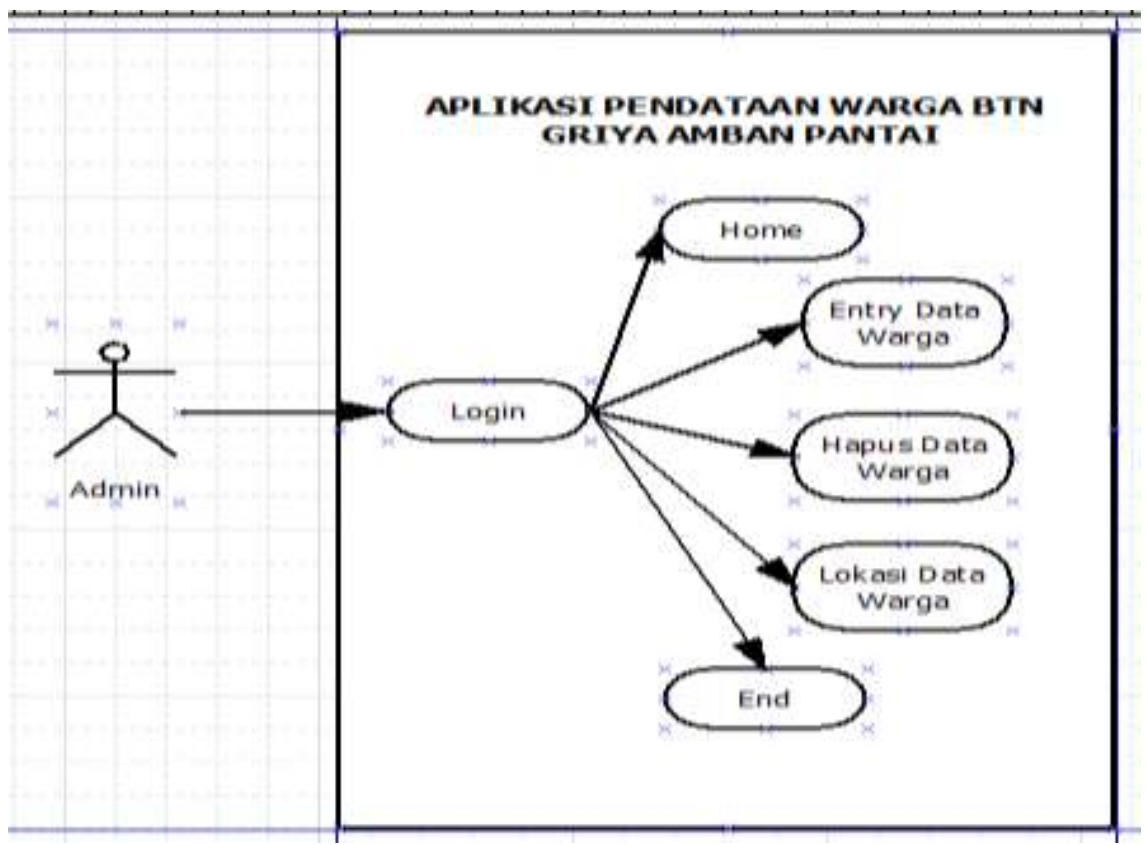

Gambar 2 : Use Case Diagram

Pada Gambar diatas aktor yaitu Admin dapat mengakses halaman yang tersedia seperti mengakses login, lihat data warga, menghapus data warga, dan melihat lokasi rumah warga. 


\section{B. Activity Diagram}

Activity diagram memperlihatkan alur langkah demi langkah dalam suatu proses. Activity diagram terdiri dari activity diagram login admin, activity diagram tambah data warga, activity diagram edit data warga, activity diagram lihat data warga, activity diagram hapus data warga dan activity diagram melihat lokasi rumah warga.

1. Activity Diagram Menu Login

Activity diagram menu login menggambarkan aktivitas yang terjadi pada menu login yang dilakukan oleh Admin.

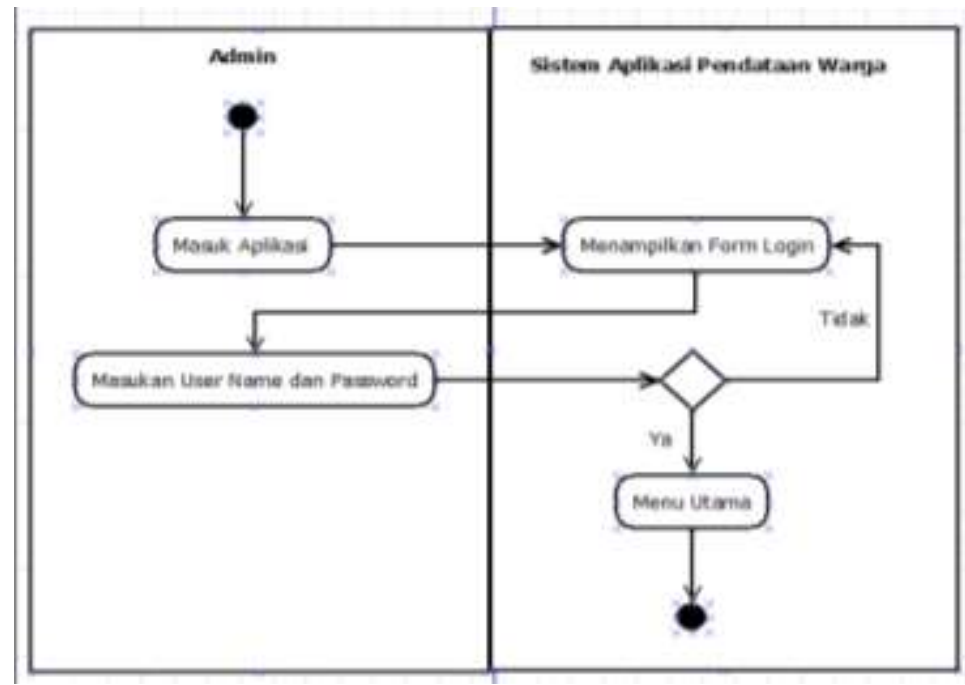

Gambar 3 : Activity Diagram Menu Login

\section{Activity Diagram Menu Entry Data Warga}

Activity diagram menu entry data warga mengambarkan aktivitas yang terjadi pada menu entry data warga.

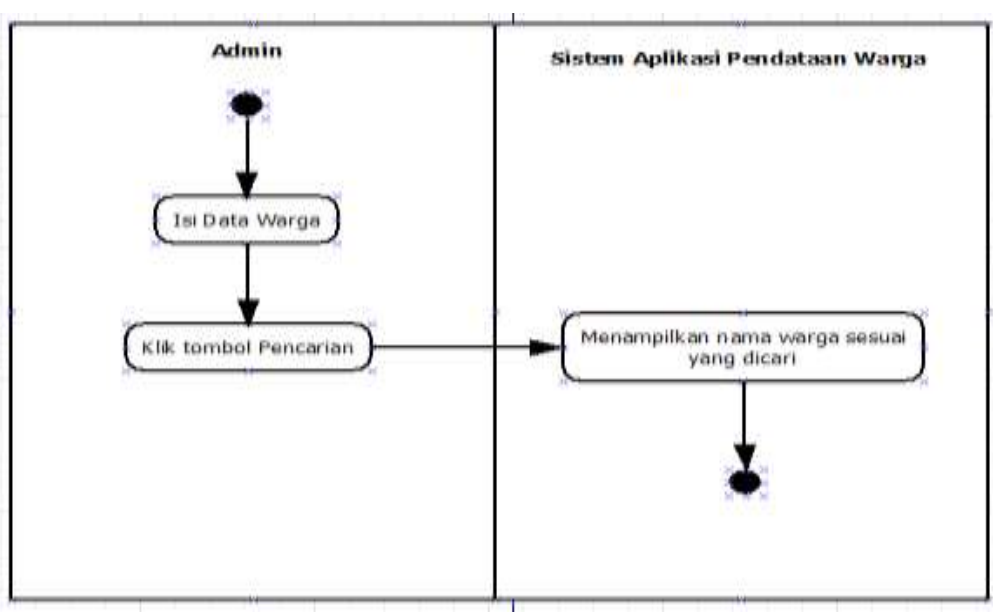

Gambar 4 : Activity Diagram Menu Entry Data Warga 
3. Activity Diagram Menu Hapus Data Warga

Activity diagram menu hapus data warga mengambarkan aktivitas yang terjadi pada menu hapus data warga.

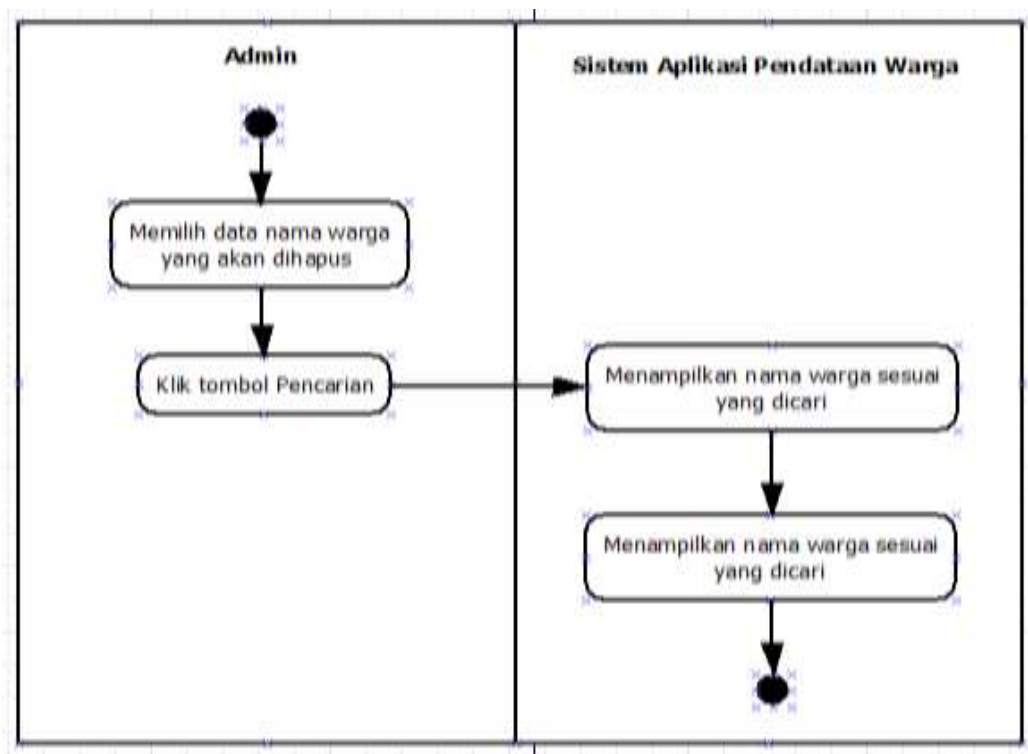

Gambar 5: Activity Diagram Menu Hapus Data Warga

4. Activity Diagram Menu Lokasi Data Warga

Activity diagram menu lokasi data warga mengambarkan aktivitas yang terjadi pada menu lokasi data warga.

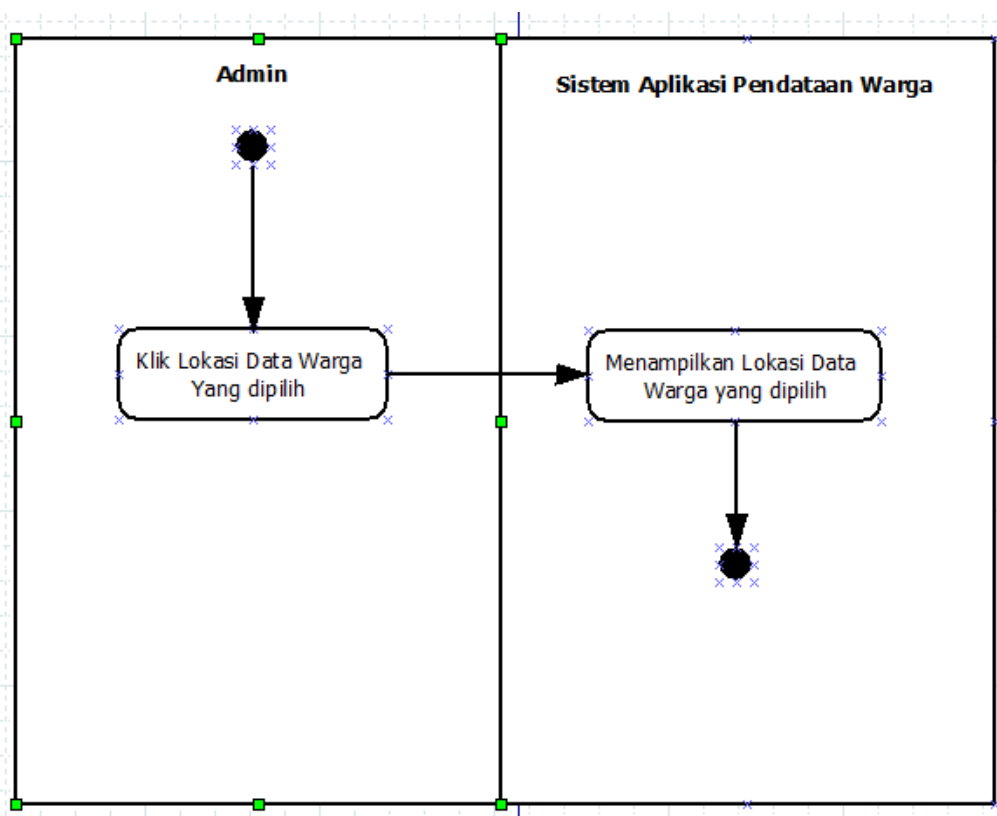

Gambar 6: Activity Diagram Menu Lokasi Data Warga 
C. Class Diagram

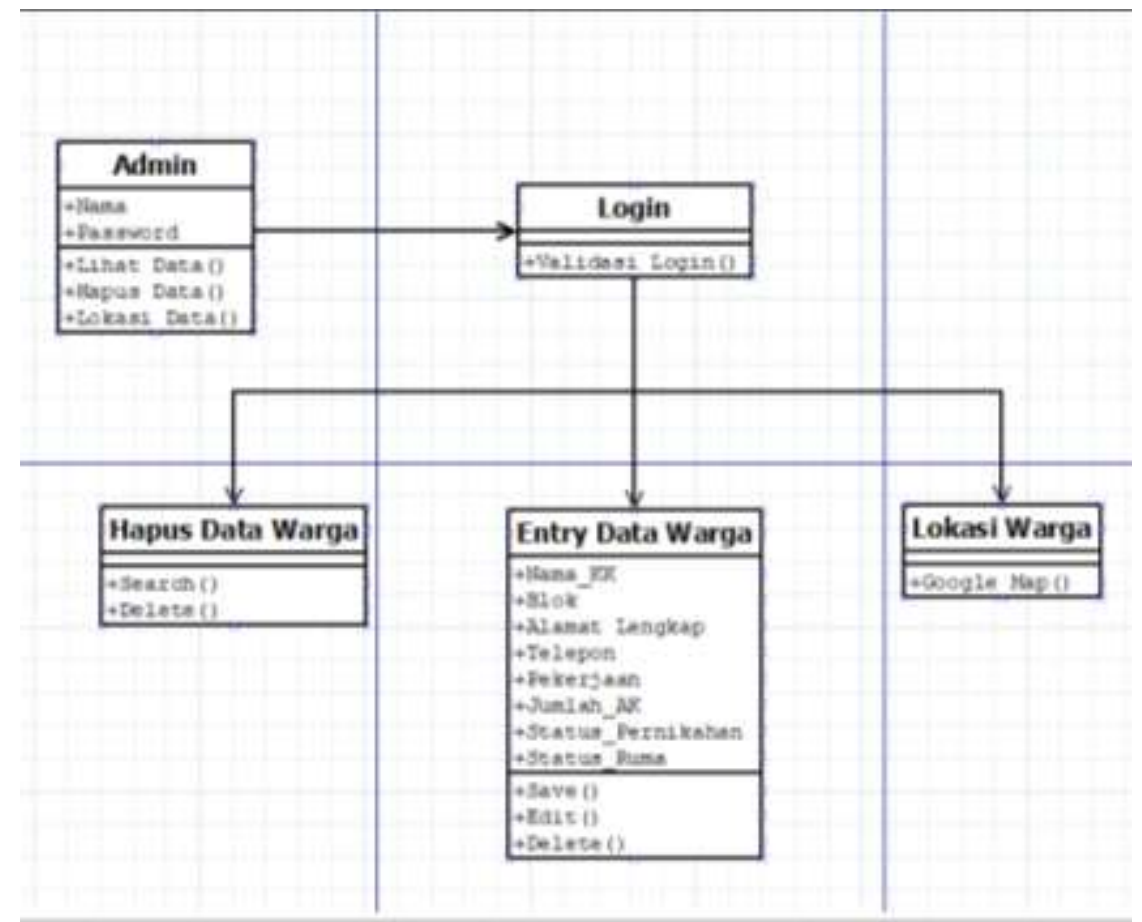

Gambar 7: Class Diagram Aplikasi Pendataan Warga

\section{Pengkodean (Coding)}

\section{A. Project}

Pembuatan project merupakan tahapan pertama saat membuat aplikasi melalui layanan app inventor. Di sini dimulai membuat project baru dengan berbagai template yang disediakan yang nantinya akan dijadikan aplikasi berbasis android. Pembuatan aplikasi terdiri dari pembuatan menu login, menu entry data warga, hapus data warga, dan lokasi data warga.

1. Pembuatan tampilan menu login

Pembuatan tampilan login admin pada aplikasi dapat dilihat pada gambar sebagai berikut : 


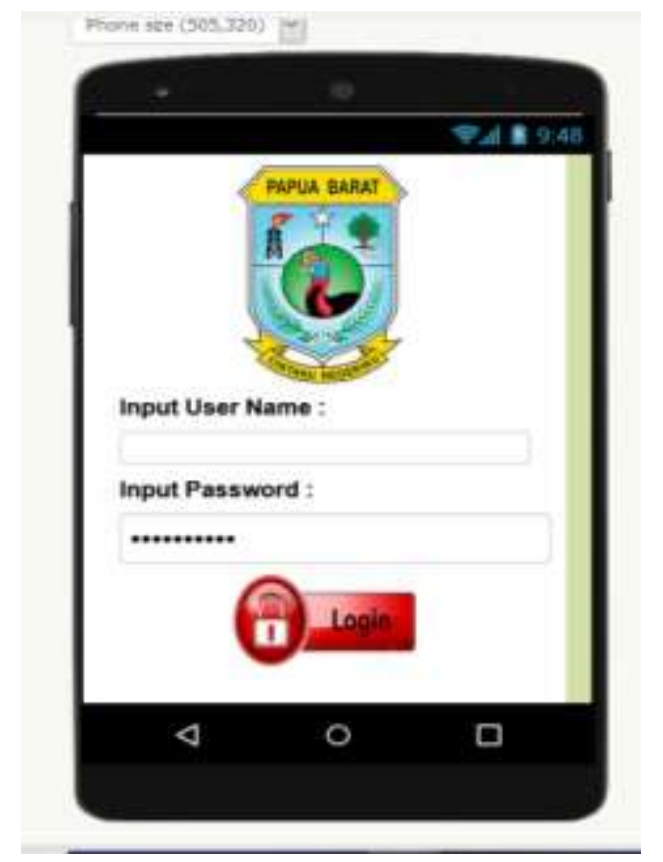

Gambar 8: Pembuatan Tampilan Login Admin

2. Pembuatan tampilan menu Pendaftaran Data Warga

Pembuatan tampilan menu pendaftaran data warga sebagai berikut :

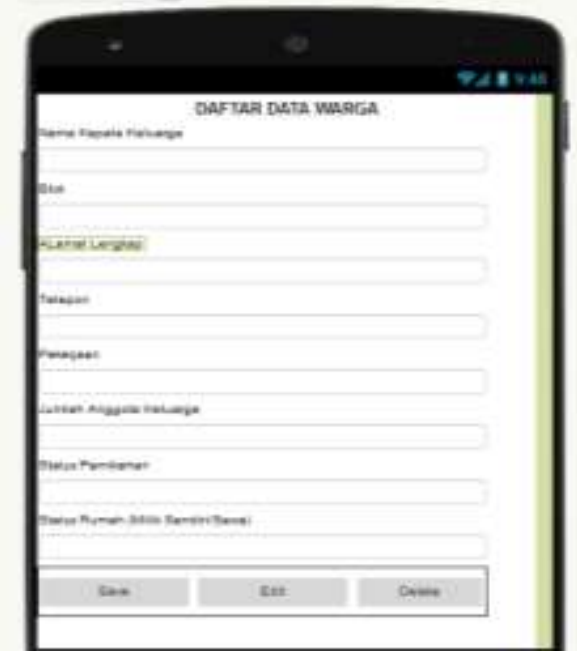

Gambar 9: Pembuatan Menu Pendaftaran Data Warga

3. Pembuatan tampilan menu Hapus Data Warga

Pembuatan tampilan menu hapus data warga adalah sebagai berikut : 


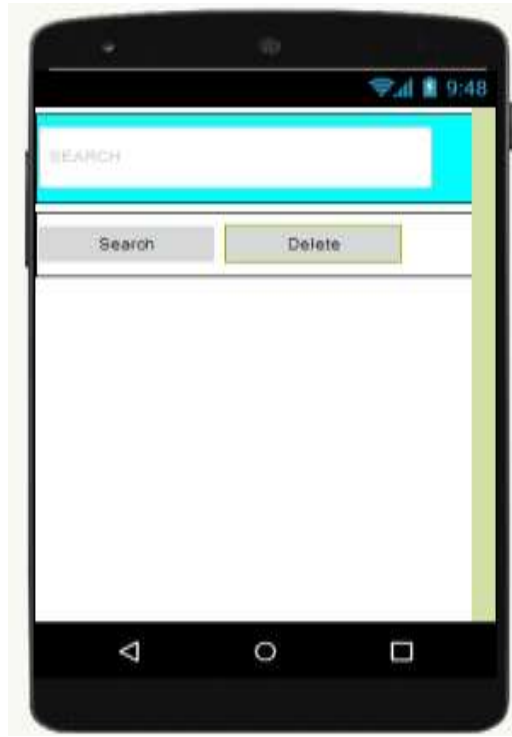

Gambar 10: Pembuatan Menu Hapus Data Warga

\section{Tampilan Lokasi}

Tampilan lokasi merupakan tampilan data posisi rumah warga yang langsung terhubung ke google map.
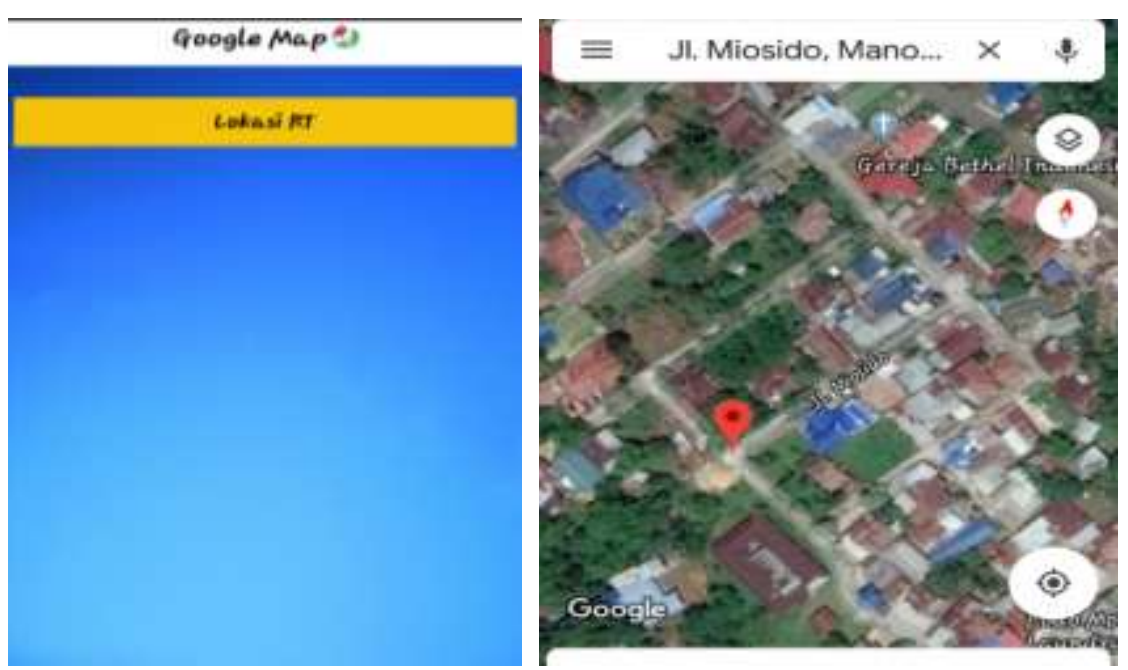

Gambar 11: Lokasi Rumah Data Warga

\section{Pengujian (Testing)}

Metode yang dilakukan penulis terhadap aplikasi pendataan warga mengunakan metode blackbox. Pengujian ini dilakukan berfokus pada spesifikasi fungsional dari perangkat lunak sehingga dengan pengujian ini dapat mendefinisikan kumpulan kondisi input dan melakukan pengetesan pada spesifikasi fungsional program. Pengujian ini sudah 
dilakukan tidak hanya pembuat, tetapi juga admin pada aplikasi pendataan warga.

Tabel 1 : Pengujian aplikasi pendataan warga mengunakan metode blackbox.

\begin{tabular}{|l|l|l|}
\hline Keterangan & \multicolumn{1}{|c|}{ Hasil Yang Diharapkan } & Hasil \\
\hline Login Admin & $\begin{array}{l}\text { Admin memasukan username dan } \\
\text { password kemudian mengklik tombol } \\
\text { login }\end{array}$ & Berhasil \\
\hline Logout Admin & $\begin{array}{l}\text { Admin klik tombol keluar di bagian } \\
\text { kanan atas kemudian keluar ke menu } \\
\text { login }\end{array}$ & Berhasil \\
\hline $\begin{array}{l}\text { Admin Tambah } \\
\text { Data Warga }\end{array}$ & $\begin{array}{l}\text { Admin klik tombol tambah } \\
\text { untuk melakukan penambahan data } \\
\text { warga }\end{array}$ & Berhasil \\
\hline $\begin{array}{l}\text { Admin Edit Data } \\
\text { Warga }\end{array}$ & $\begin{array}{l}\text { Admin klik tombol Edit Data } \\
\text { melakukan perubahan data warga }\end{array}$ & Berhasil \\
\hline $\begin{array}{l}\text { Admin Hapus Data } \\
\text { Warga }\end{array}$ & $\begin{array}{l}\text { Admin klik tombol Delete untuk } \\
\text { melakukan hapus data warga }\end{array}$ & Berhasil \\
\hline $\begin{array}{l}\text { Admin } \\
\text { menginputkan } \\
\text { data Warga }\end{array}$ & Data warga berhasil di tambahkan & Berhasil \\
\hline $\begin{array}{l}\text { Admin edit data } \\
\text { Warga }\end{array}$ & Data warga berhasil diubah & Berhasil \\
\hline $\begin{array}{l}\text { Admin hapus } \\
\text { data Warga }\end{array}$ & $\begin{array}{l}\text { Admin berhasil menghapus data } \\
\text { warga }\end{array}$ & Berhasil \\
\hline $\begin{array}{l}\text { Admin lihat data } \\
\text { Warga }\end{array}$ & $\begin{array}{l}\text { Menampilkan data warga yang } \\
\text { dicari }\end{array}$ & Berhasil \\
\hline $\begin{array}{l}\text { Admin Lihat } \\
\text { lokasi }\end{array}$ & Menampilkan lokasi data warga & Berhasil \\
\hline
\end{tabular}

\section{KESIMPULAN}

Dari hasil penelitian, perancangan dan implementasi yang dilakukan maka ada beberapa kesimpulan yang diambil yaitu sebagai berikut:

1. Berdasarkan pengujian dengan mengunakan metode blackbox maka Aplikasi pendataan warga BTN. Griya Amban Pantai telah berhasil dengan baik.

2. Dengan adanya Aplikasi berbasis smartphone ini maka warga BTN. Amban Pantai dapat mempermudah ketua RT dalam menambahkan data dan mencari data warga. 
3. Warga diberikan kemudahan dalam mendaftarkan diri kepada ketua RT karena mengunakan handphone dengan biaya yang murah dan waktu yang tidak terbatas.

\section{DAFTAR PUSTAKA}

Andi Mariani, Sri Ariyanti Sabiku (2016), Sistem Pendataan Penduduk di Kantor Desa Ibarat, Jurnal JTII,1(1), 16-20.

Ditama A K, dkk (2014), Rancang Bangun Aplikasi Pendataan Warga Banjar Berbasis Android, E- Journal SPEKTRUM, 1(1), 65-66.

Febri Haswan (2018), Perancangan Sistem Informasi Pendataan Penduduk Kelurahan Sungai Jaring Berbasis Web dengan Object Oriented Programming, Jurnal Teknologi dan Open Source,1(2), 92-100.

Ii Sopiandi (2020), Sistem Informasi Pendataan Penduduk Berbasis Web, Jurnal Sistem Informasi,7(2), 97-103.

Kurniawati Rachael. (2016). Pengembangan Sistem Informasi Kependudukan Bebasis Mobile dan Restful Web Server. Universitas Atma Jaya. Yogyakarta.

Mulyadi. (2011). Sistem Perencanaan dan Pengendalian Manajemen. Jakarta : Selemba Empat.

Ni Kadek Ceryna Dewi, dkk (2018), Rancang Bangun Aplikasi Mobile Siska Berbasis Android, Jurnal SINTECH, 1(2), 100-107.

Nugroho, Adi. (2010). Analisis Perancangan Sistem Informasi dengan Metodologi Berorientasi Object. Bandung: Informatika.

Suprianto, Dodit dan Rini Agustina. (2012). Pemograman Aplikasi Android. Yogyakarta : MediaKom.

Sukmato \& Shalahuddin. (2013). Analisa Dan Desain Sistem Informasi. Yogyakarta : Andi Offset. 